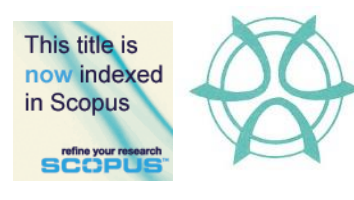

PLANNING MALAYSIA:

Journal of the Malaysian Institute of Planners

VOLUME 15 ISSUE 1 (2017), Page 255 - 260

\title{
HOUSING AFFORDABILITY IN THE STATE OF MELAKA
}

\author{
Mariana Mohamed Osman', Noor Suzilawati Rabe ${ }^{2}$, Muhammad Faris Abdullah ${ }^{3}$, \\ Nur Farhanah Rosli ${ }^{4}$, \& Farah Eleena Zainudin ${ }^{5}$ \\ ${ }^{1,2,3,4}$ Kulliyyah of Architecture and Environmental Design, \\ INTERNATIONAL ISLAMIC UNIVERSITY MALAYSIA
}

\begin{abstract}
Housing is a basic need to man. It provides shelter and comfort from the elements and improve quality of life of the residents. Hence, housing should be affordable to all. This paper assesses the housing affordability for the districts in Melaka. This was achieved by calculating the median multiple of the price income ratio and comparing the score to the housing affordability index. Secondary data were obtained from reports published by the governmental agencies. The results show that housing is mostly moderately unaffordable in the districts of Melaka. Additionally, housing affordability has improved from 2012 to 2014 in majority of the districts.
\end{abstract}

Keyword: Housing affordability, affordable housing price, district, Melaka.

Date Received: $30^{\text {th }}$ April 2016

Date of Acceptance: $30^{\text {th }}$ October 2016 
Mariana Mohamed Osman, Noor Suzilawati Rabe, Muhammad Faris Abdullah, Nur Farhanah, \& Farah Eleena Housing Affordability in The State of Melaka

\section{INTRODUCTION}

Owning a home for shelter and comfort is considered by many as a life goal and a measure of personal success (Hashim, 2010). However, the price of houses is increasing, so much so that housing has become unaffordable to many. In Malaysia, the same situation occurs where house price is surging upwards, unproportionately to income. Land scarcity and economic growth have often been cited as the factors that drive house price up to the point that it becomes unaffordable to the majority of Malaysian public (Hashim, 2010). As Malaysia aspires to be a developed nation with high-income economy by 2020 , the housing industry needs to be adaptive and responsive to demand for special groups, especially the medium and low income earners. ISIS (2013) proposes that the Government must take appropriate measures to ensure access to quality and affordable housing is enjoyed by all. ISIS (2013) also notes that as public purchasing power has reduced, housing affordability gap has widened even further. However, Chang (2013) argues that the determining factors on the ability to purchase a property is not dependable solely on income but also by the high house price and the mortgage interest rate. Making houses affordable, especially to the lower income group is critical for poverty reduction, institution building, good governance at the local and national levels, and conflict prevention. (Shuid, 2016).

The objective of this paper is to provide an overview of the affordable housing scenario in Melaka and to determine the housing affordability index for each districts in Melaka. It is hoped that the findings from this paper would contribute in making housing more affordable to the Malaysian public.

\section{SITE PROFILE}

Melaka is a state in Malaysia and located in the southern region of the Peninsular Malaysia. The state borders the famous Straits of Malacca on the west, Negeri Sembilan to the north and Johor to the south. Melaka is also well known by the inclusion of its city centre in the UNESCO World Heritage Site. Melaka is one of the smaller states in Malaysia, measuring a little over 165,000 hectares. The state is made up of three districts, which are Melaka Tengah, Jasin and Alor Gajah. Alor Gajah is the largest district in the state, but Melaka Tengah, although the smallest district, has the highest number of population. The historic Melaka City Centre is located in the Melaka Tengah district.

\section{AFFORDABLE HOUSING IN MELAKA}

Affordability is defined as 'the ability of households to meet housing costs, while maintaining the ability to cover other basic living costs' (AHURI, 2004). Meanwhile, Shaqra'a, Badarulzaman and Roosli (2015) define affordability as appropriate and reasonable house price based on its quality and location. In terms of housing affordability, Khazanah Research Institute (2015) ranks Melaka as the 
PLANNING MALAYSIA

Journal of the Malaysia Institute of Planners (2017)

state with the most affordable housing in Malaysia. In fact, according to KRI (2015), Melaka is the only state in Malaysia that achieved a median multiple of 3.0 in 2014, indicating that housing in Melaka is affordable to its population.

Melaka is also one of the few states in Malaysia that has established its own Housing Board. The Melaka Housing Board is a state government agency that oversees housing development projects in Melaka. The Board was established in 2002 through the passing of the Melaka Housing Board Enactment 2002. Prior to the establishment of the Board, housing development projects in the state were monitored by the State level housing department and the local authorities of the area.

\section{METHODOLOGY}

Affordable housing is related to the ability of a household to pay for their house (EsruqLabin, 2014). The concept of housing affordability can be measured from three perspectives, namely Repayment Affordability, Purchase Affordability and Price Income Ratio (PIR). For the calculation of housing affordability index (HAI) for each district in Melaka, the PIR was used. To derive the HAIs, the median multiple formula, which makes use of the annual income and median of all house prices, was employed (Figure 1). Data on population income and house price for year 2012 and 2014 were sourced from the Department of Statistics Malaysia and the National Property Information Centre of the Valuation and Property Services Department Malaysia.

$$
\text { Median Multiple }=\frac{\text { Median All House Price }}{\text { Annual Medium Income }}
$$

Figure 1 Median Multiple Formula Source: Khazanah Research Institute, 2015

The resulting median multiple scores were then compared to the housing affordability index categories as shown in Table 2 below.

Table 2 Housing Affordability Rating Categories

\begin{tabular}{l|c}
\hline Rating & Median multiple \\
\hline Severely unaffordable & 5.1 and above \\
\hline Seriously unaffordable & $4.1-5.0$ \\
\hline Moderately unaffordable & $3.1-4.0$ \\
\hline Affordable & 3.0 and below \\
\hline Source: Demographia, 2016. &
\end{tabular}

\section{FINDINGS}

Table 3 shows the housing affordability index by districts in Melaka for year 2012 and 2014. On average, housing affordability in Melaka has improved from year 
Mariana Mohamed Osman, Noor Suzilawati Rabe, Muhammad Faris Abdullah, Nur Farhanah, \& Farah Eleena Housing Affordability in The State of Melaka

2012 to 2014. The district of alor Gajah recorded HAI of seriously unaffordable in 2012, has improved to moderately unaffordable in 2014. For the district of Melaka Tengah, although the HAI for both years remained at moderately unaffordable, the median multiple has reduced to 3.1 in 2014 from 3.6 in 2012. However, for the district of Jasin, the HAI has worsened from moderately unaffordable in 2012 to seriously unaffordable in 2014. At state level, the study KRI (2015) shows that the HAI has improved from moderately unaffordable in 2012 to affordable in 2014.

Table 3 also shows that there was a substantial increase in the annual median income for both Alor Gajah and Jasin. This helped to lower the median multiple score for the districts, resulting in improved HAIs. Similar situation also occurred at state level where the percentage increase in annual median income was larger than the percentage increase in median house price, resulting in improved HAI. In Jasin, the percentage increase of income is lower than that of house price, which led to worsening HAI.

Table 3 Housing Affordability Index in Melaka by Districts in 2012 and 2014

\begin{tabular}{|c|c|c|c|c|c|c|c|c|}
\hline \multirow[b]{2}{*}{ District } & \multicolumn{4}{|c|}{2012} & \multicolumn{4}{|c|}{2014} \\
\hline & 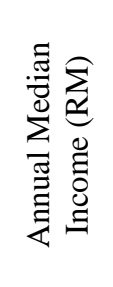 & 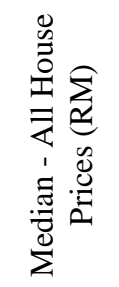 & 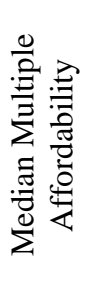 & $\underset{\mathbb{I}}{\mathbb{I}}$ & 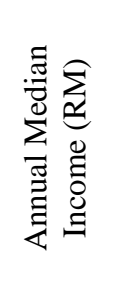 & 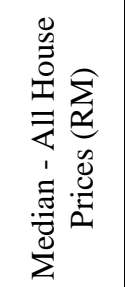 & 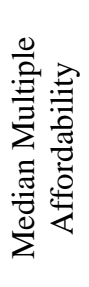 & $\underset{I}{\mathbb{I}}$ \\
\hline $\begin{array}{c}\text { Alor } \\
\text { Gajah }^{\#}\end{array}$ & 38,370 & 185,500 & 4.8 & $\begin{array}{c}\text { Seriously } \\
\text { Unaffordable }\end{array}$ & 56,628 & 190,000 & 3.4 & $\begin{array}{l}\text { Moderately } \\
\text { Unaffordable }\end{array}$ \\
\hline $\operatorname{Jasin}^{\#}$ & 36,523 & 140,000 & 3.8 & \multirow{2}{*}{$\begin{array}{c}\text { Moderately } \\
\text { Unaffordable }\end{array}$} & 53,520 & 221,000 & 4.1 & $\begin{array}{c}\text { Seriously } \\
\text { Unaffordable }\end{array}$ \\
\hline $\begin{array}{l}\text { Melaka } \\
\text { Tengah }^{\#}\end{array}$ & 44,977 & 160,000 & 3.6 & & 62,940 & 195,913 & 3.1 & $\begin{array}{c}\text { Moderately } \\
\text { Unaffordable }\end{array}$ \\
\hline $\begin{array}{l}\text { Overall } \\
\text { Melaka* }\end{array}$ & 47,076 & 160,000 & 3.4 & $\begin{array}{c}\text { Moderately } \\
\text { Unaffordable }\end{array}$ & 60,348 & 180,000 & 3 & Affordable \\
\hline
\end{tabular}

\section{RECOMMENDATION}

Despite the affordable HAI for the state of Melaka, housing is still found to be unaffordable at district level (Table 3). Hence, Table 4 shows the suggested median house price for the districts in order to meet the affordable HAI rating (i.e. median multiple score of 3.0). The suggested median house price is derived by multiplying the 2014 annual median income of each district by 3.0 . 
PLANNING MALAYSIA

Journal of the Malaysia Institute of Planners (2017)

Table 4 Housing Affordability Index of Ration by Median All House Prices

\begin{tabular}{|l|c|c|c|}
\hline \multicolumn{1}{|c|}{ District } & $\begin{array}{c}\text { Annual Median } \\
\text { Income 2014 (RM) }\end{array}$ & $\begin{array}{c}\text { Median All house } \\
\text { Price 2014 (RM) }\end{array}$ & $\begin{array}{c}\text { Proposed Affordable } \\
\text { Median House Price } \\
\text { (RM) }\end{array}$ \\
\hline Jasin & 53,520 & 221,000 & RM 160,560 \\
\hline Alor Gajah & 56,628 & 190,000 & RM 169,884 \\
\hline Melaka Tengah & 62,940 & 195,913 & RM188,820 \\
\hline Overall Melaka & 60,348 & 180,000 & RM181,044 \\
\hline
\end{tabular}

Source: Authors own calculation

Earlier findings show that Jasin experienced worsening HAI from 2012 to 2014. To achieve affordable HAI rating, the median house price for the district of Jasin is proposed to be capped at a maximum price of RM160,560. Meanwhile, for the districts of Alor Gajah and Melaka Tengah, the proposed price are RM169,884 and RM188,820, respectively.

Figure 2 compares the 2014 median house price and the proposed median house price for each district in Melaka. Again, it can be seen that difference between the 2014 median house price and the proposed median house price is largest in the district of Jasin. This corroborates the findings that Jasin has the worst HAI as compared to the other districts in Melaka (Table 3). Melaka Tengah has the smallest difference between the two prices. This is reflected in the 3.1 median multiple score for the district, which is only slightly above the affordable rating of 3.0.

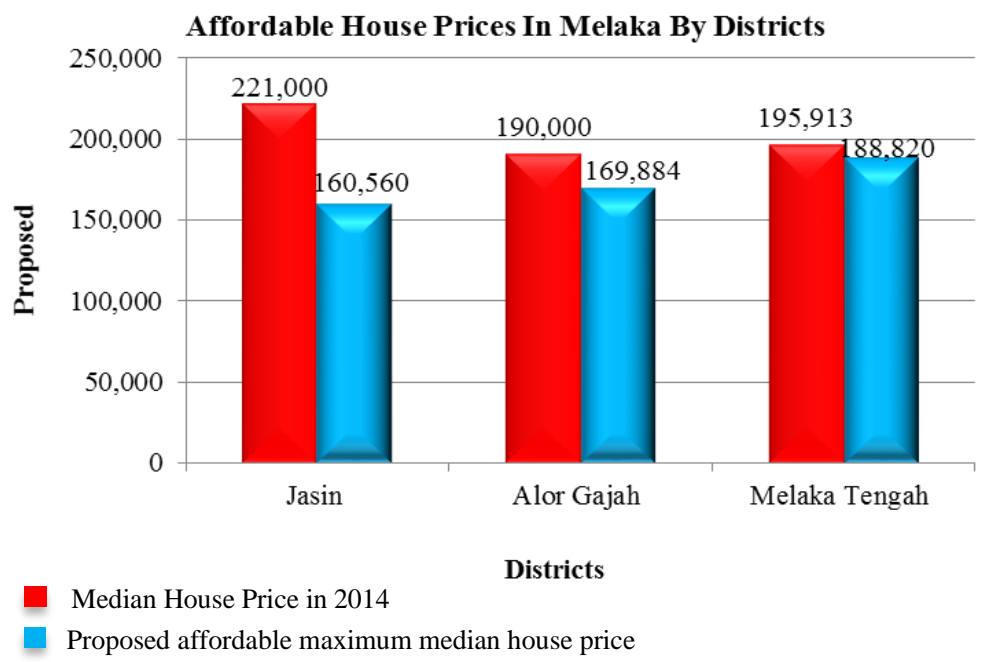

Figure 2 Comparison between 2014 Median House Price and Proposed Affordable Median House Price for Districts in Melaka 
Mariana Mohamed Osman, Noor Suzilawati Rabe, Muhammad Faris Abdullah, Nur Farhanah, \& Farah Eleena Housing Affordability in The State of Melaka

\section{CONCLUSION}

This paper has shown that despite the affordable HAI of the state, at district level housing was still unaffordable in Melaka. Nevertheless, the level of unaffordability was not severe. Only one district recorded a seriously unaffordable HAI, while the other two were at moderately unaffordable. However, measures must be undertaken by the state and local governments in Melaka to ensure that the population of each of the district can truly enjoy access to affordable and quality housing.

\section{REFERENCES}

AHURI [Australian Housing and Research Institute] (2004). Measuring housing affordability. AHURI Research and Policy Bulletin, 45.

Chang, H. t.-I. (2010). A study of rural economy in Yunnan. Yunnan, China.

Demographia (2016). 12 ${ }^{\text {th }}$ Annual Demographia International Housing Survey.

Esruq-Labin, A. M. J., Che Ani, A. I., Mohd Tawil, N., Nawi, M. N. M., \& Othuman Mydin, M. A. (2014). Criteria for affordable housing performance measurement: a review. In Proceedings of the Emerging Technology for Sustainable Development Congress, August 5, Bangi, Malaysia.

Hashim, Z. A. (2010) House price and affordability in housing in Malaysia. Akademika, 78, 37-46.

Khazanah Research Institute [KRI] (2015). Making housing affordable. Kuala Lumpur: Khazanah Research Institute.

Shaqra'a, E., Badarulzaman, N., \& Roosli, R. (2015). Residents' perception of the affordability of private housing schemes: lessons from Aden, Yemen. Procedia - Social and Behavioural Sciences, 202, 389-399.

Shuid, S. (2016). The housing provision system in Malaysia. Habitat International, 54 (3), 210-223. 